\title{
T-Box Transcription Factor T
}

National Cancer Institute

\section{Source}

National Cancer Institute. T-Box Transcription Factor T. NCI Thesaurus. Code C84458.

T-box transcription factor T (435 aa, $\sim 47 \mathrm{kDa}$ ) is encoded by the human TBXT gene.

This protein is involved in the regulation of both mesoderm development and transcription. 